\title{
Nodal involvement pattern in resectable lung cancer according to tumor location
}

\author{
This article was published in the following Dove Press journal: \\ Cancer Management and Research \\ 6 June 2012 \\ Number of times this article has been viewed
}

\author{
Somcharoen Saeteng' \\ Apichat Tantraworasin' \\ Juntima Euathrongchit ${ }^{2}$ \\ Nirush Lertprasertsuke ${ }^{3}$ \\ Yutthaphun Wannasopha ${ }^{2}$ \\ 'Department of Surgery, Faculty \\ of Medicine, Chiang Mai University, \\ Thailand, ${ }^{2}$ Department of Radiology, \\ Faculty of Medicine, Chiang Mai \\ University, Thailand, ${ }^{3}$ Department \\ of Pathology, Faculty of Medicine, \\ Chiang Mai University, Thailand
}

Correspondence: Apichat Tantraworasin Department of Surgery, Faculty of Medicine, Chiang Mai University, Chiang Mai 50200, Thailand

Tel 0 II -66-53-945533

Fax 0II-66-53-946I39

Emailohm_med@hotmail.com

\begin{abstract}
The aim in this study was to define the pattern of lymph node metastasis according to the primary tumor location. In this retrospective cohort study, each of the operable patients diagnosed with lung cancer was grouped by tumor mass location. The International Association for the Study of Lung Cancer nodal chart with stations and zones, established in 2009, was used to define lymph node levels. From 2006 to 2010, 197 patients underwent a lobectomy with systematic nodal resection for primary lung cancer at Chiang Mai University Hospital. There were 123 male and 74 female patients, with ages ranging from 16-85 years old and an average age of 61.31. Analyses of tumor location, histology type, and nodal metastasis were performed. The locations were the right upper lobe in 63 patients (31.98\%), the right middle lobe in 18 patients (9.14\%), the right lower lobe in 30 patients $(15.23 \%)$, the left upper lobe in 55 patients $(27.92 \%)$, the left lower lobe in 16 patients $(8.12 \%)$, and mixed lobes (more than one lobe) in 15 patients (7.61\%). The mean tumor size was $4.45 \mathrm{~cm}$ in diameter (range $1.2-16.5 \mathrm{~cm}$ ). Adenocarcinoma was the most common histological type, which occurred in 132 cases $(67.01 \%)$, followed by squamous cell carcinoma in 41 cases $(20.81 \%)$, bronchiolo alveolar cell carcinoma in nine cases $(4.57 \%)$, and large cell carcinoma in seven cases (3.55\%). Eighteen cases (9.6\%) had skip metastasis (mediastinal lymph node metastasis without hilar node metastasis). Adenocarcinoma and intratumoral lymphatic invasion were the predictors of mediastinal lymph node metastases. There were statistically significant differences between a tumor in the right upper lobe and the right lower lobe. However, there were no statistically significant differences between tumors in the other lobes. In conclusion, tumor location is not a precise predictor of the pattern of nodal metastasis. Systematic lymph node dissection is the only way to accurately determine lymph node status. Further studies are required for evaluation and conclusions.
\end{abstract}

Keywords: lung cancer, nodal metastasis

\section{Background and introduction}

Lung cancer is a major public health problem worldwide, including in Thailand. The most recent data on cancer incidence in Thailand is from the National Cancer Institute in Bangkok, ${ }^{1}$ which indicates lung cancer is the second most common cancer in males $(24.9 \%)$ and the fourth most common cancer in females $(9.7 \%)$. Currently, there are three primary methods of treatment for these patients. Surgical treatment includes a complete hilar and mediastinal lymphadenectomy, also called radical systematic mediastinal lymph node dissection. With this option, the aim is to achieve better local control, an improved survival rate, and complete lung cancer staging. However, the prognostic impact (improvement of local control and postoperative survival) of this procedure has yet to be determined. Many researchers debate whether systematic nodal 
dissection or sampling nodal dissection is the most effective dissection method. Su et $\mathrm{al}^{2}$ and other researchers ${ }^{3-6}$ conclude that systematic nodal dissection can improve the chances of survival and help accurately identify cancer stages. However, some researchers ${ }^{7-9}$ argue that nodal dissection sampling is acceptable. Therefore, the present attitude of surgeons toward possible mediastinal lymph node metastasis in lung cancer varies from one institution to another. Surgical options include nodal sampling, radical systematic lymph node dissection, and bilateral radical lymph node dissection via sternotomy because of unanswered questions about lymphatic spreading patterns.

This retrospective cohort study was performed to define the nodal status of patients diagnosed with lung cancer who received surgery to determine the pattern of lymphatic drainage in the thorax, which may be useful for surgeons and radiologists in estimating nodal involvement and determining a surgical strategy.

\section{Patients and methods}

After being accepted by the institutional review board, 197 patients with clinical resectable non-small cell lung cancer underwent a lobectomy and systemic nodal resection at Chiang Mai University Hospital between January 2006 and December 2010. The pathological results were retrospectively reviewed for 123 male and 74 female patients, with ages ranging from 16-85 years old and an average age of 61.31 (Table 1). Before the operation, each patient underwent a physical examination, pulmonary function test, blood chemistry analysis, plain chest roentgenography, and thoracic computed tomography (CT) scanning to determine the clinical staging. Based on the CT scans, mediastinal lymph nodes less than or equal to $1 \mathrm{~cm}$ along the short axis were defined as not metastatic. A mediastinoscopy with biopsy was performed only in patients with mediastinal lymph nodes larger than $1 \mathrm{~cm}$. If mediastinal lymph node disease was found, neoadjuvant chemotherapy was administered and the patient was excluded from this study. Positron emission tomography is not available at our institute. Patients diagnosed with pathological nodal group 2 disease and treated with neoadjuvant chemotherapy were also excluded from this study. Eleven patients in this study received an open thoracotomy, lobectomy, and routine systematic nodal dissection, in accordance with The International Association for the Study of Lung Cancer, ${ }^{10}$ regardless of tumor size or histology type. All dissected lymph nodes were sent for pathological examination and metastatic status determination. Those with pathological
Table I Patient characteristics

\begin{tabular}{ll}
\hline Characteristics & Number (\%) \\
\hline Gender & \\
Male & $123(62.5)$ \\
Female & $74(37.6)$ \\
Age (year) mean \pm SD & $61.3 \pm 11.0$ \\
Histology type & \\
Adenocarcinoma & $132(67.0)$ \\
Squamous cell carcinoma & $4 I(20.9)$ \\
Others & $24(12.2)$ \\
Tumor location & \\
Right upper lobe & $63(32.0)$ \\
Right middle lobe & $18(9.1)$ \\
Right lower lobe & $30(15.2)$ \\
Left upper lobe & $55(28.0)$ \\
Left lower lobe & $16(8.1)$ \\
Right upper lobe adhered to right middle lobe & $1 \mathrm{II}(5.6)$ \\
Right lower lobe adhered to right middle lobe & $2(1.0)$ \\
Left upper lobe adhered to left lower lobe & $2(1.0)$ \\
Pathological tumor status & \\
TIa & $14(7.1)$ \\
TIb & $46(23.4)$ \\
T2a & $93(47.2)$ \\
T2b & $23(11.7)$ \\
T3 & $21(10.7)$ \\
T4 & $0(0)$ \\
Pathological nodal status & \\
No & $128(65.0)$ \\
NI & $19(9.6)$ \\
N2 & $50(25.4)$ \\
N3 & $0(0)$ \\
Pathological staging & \\
la & $38(19.3)$ \\
lb & $59(30.0)$ \\
Illa & $30(15.2)$ \\
Ilb & $17(8.6)$ \\
IIla & $53(26.9)$ \\
IIlb & $0(0)$ \\
IV & $0(0)$ \\
\hline
\end{tabular}

nodal group 2 disease received postoperative chemotherapy. If the tumor invaded more than one lobe, a bilobectomy was performed. The collected data included age, sex, primary tumor location and size, histological types, nodal sites, and pathological staging. Each nodal site was divided into four categories. The upper mediastinal nodal group included low cervical nodes (station 1), upper paratracheal nodes (station 2), prevascular and retrotracheal nodes (station 3 ), and lower paratracheal nodes (station 4). The lower mediastinal nodal group included subcarinal nodes (station 7), paraesophageal nodes (station 8), and pulmonary ligament nodes (station 9). The intrapulmonary nodal group included hilar nodes (station 10), interlobar nodes (station 11), lobar nodes (station 12), segmental nodes (station 13), and subsegmental nodes (station 14). The aortopulmonary 
Table 2 Histological cell type in each lobe

\begin{tabular}{llllllll}
\hline & Adenocarcinoma & BAC & SCCA & Small cell CA & Large cell CA & Neuro-endocrine & Total (\%) \\
\hline RUL & 47 & 2 & 10 & - & 2 & I & $63(32.0)$ \\
RML & II & 2 & 3 & 2 & & - & $18(9.1)$ \\
RLL & 20 & 1 & 6 & 1 & 2 & 1 & $30(15.2)$ \\
LUL & 31 & 1 & 21 & 1 & 1 & 1 & $55(29.9)$ \\
LLL & 14 & 2 & & & 2 & $16(8.1)$ \\
Mixed & 9 & 2 & 2 & & $15(7.6)$ \\
\hline
\end{tabular}

Abbreviations: BAC, Bronchioloalveolar carcinoma; SCCA, squamous cell carcinoma; RUL, right upper lobe; RML, right middle lobe; RLL, right lower lobe; LUL, left upper lobe; LLL, left lower lobe; Mixed, RUL and RML or RLL and RML.

nodal group included subaortic (aortopulmonary window) nodes (station 5) and para-aortic nodes (ascending aorta or phrenic) (station 6).

Statistical analysis was performed using the STATA statistical package. The data was expressed as mean and standard deviation unless otherwise stated. A student's $t$-test was used to ascertain the statistical significance of two continuous variables. Fisher exact probability analysis was performed to test for differences in proportions of categorical variables between two or more groups. The diagnostic accuracy parameters were compared using compatible statistical analysis. Univariable and multivariable logistic regression analyses were used to control the confounders. The level of significance was set to a $P$ value of less than 0.05 .

\section{Results}

\section{Patient characteristics}

There were 197 patients whose primary lung cancer was clinically classified as resectable disease (stage IA, IB, IIA, IIB, and some instances of IIIA). The age range of the patients was from 16-85 years, with a mean age of 61.3. Preoperative mediastinoscopic biopsies were performed for 27 patients
$(13.7 \%)$ and these patients were negative for malignant cells. Twenty-one patients were excluded from this study because of a positive mediastinal lymph node based on a mediastinoscopic biopsy (not included in the 197 patients). Lymph node station one or low cervical node (N3 group) was dissected in two patients and was negative for malignant cells (no metastasis). Primary tumors were located in the right upper lobe (RUL) in 63 cases $(32.0 \%)$, in the right middle lobe (RML) in 18 cases $(9.1 \%)$, in the right lower lobe (RLL) in 30 cases $(15.2 \%)$, in the left upper lobe (LUL) in 55 cases $(28.0 \%)$, in the left lower lobe (LLL) in 16 cases $(8.1 \%)$, in both RULs adhered to the RML in 11 cases $(5.6 \%)$, in the RLL adhered to the RML in two cases (1.0\%), and in the LUL adhered to the LLL in two cases (1.0\%). Tumors were typed and staged as shown in Tables 1 and 2 . Two cases were pathologically diagnosed as small cell carcinoma since the preoperative diagnoses were unavailable.

\section{The predictors of intrathoracic lymph node metastases}

These patients were divided into two groups, negative malignant cells in the intrathoracic lymph node group and positive

Table 3 Patient characteristics of positive and negative malignant cells in intrathoracic lymph nodes

\begin{tabular}{|c|c|c|c|}
\hline Characteristics & $\begin{array}{l}\text { Negative malignant cells } \\
\text { in intrathoracic LN } \\
\mathbf{N}=128\end{array}$ & $\begin{array}{l}\text { Positive malignant cells } \\
\text { in intrathoracic LN } \\
N=69\end{array}$ & $P$ value \\
\hline Tumor size, cm (mean $\pm S D)$ & $4.7 \pm 2.5$ & $4.3 \pm 2.3$ & 0.852 \\
\hline \multicolumn{4}{|l|}{ Histology type (number (\%)) } \\
\hline Small cell carcinoma & $2(1.6)$ & $0(0.0)$ & 0.543 \\
\hline Non-small cell carcinoma & $126(98.4)$ & $69(100.0)$ & 0.043 \\
\hline Adenocarcinoma & $107(83.6)$ & $66(95.7)$ & 0.012 \\
\hline Squamous cell carcinoma & $9(7.0)$ & $0(0.0)$ & 0.028 \\
\hline Others & $10(7.8)$ & $3(4.4)$ & 0.549 \\
\hline Lymphatic invasion & $100(78.1)$ & $64(92.6)$ & 0.009 \\
\hline Cell differentiated & & & 0.123 \\
\hline Well differentiated & $13(10.2)$ & $2(2.9)$ & 0.091 \\
\hline Moderately differentiated & $36(28.1)$ & $28(40.6)$ & 0.082 \\
\hline Poorly differentiated & $50(39.1)$ & $27(39.1)$ & 1.000 \\
\hline Undifferentiated & $29(22.7)$ & $12(17.4)$ & 0.463 \\
\hline
\end{tabular}

Note: Intrathoracic lymph nodes refer to mediastinal lymph nodes (N2 group) and intrapulmonary lymph node (NI group). Abbreviation: $\mathrm{LN}$, lymph node. 
malignant cells in the intrathoracic lymph node group. Patient characteristics, including tumor size, histology types, intratumoral lymphatic invasion, and cell differentiation are shown in Table 3. There were statistically significant differences in histology types and lymphatic invasion. Patients diagnosed with adenocarcinoma or intratumoral lymphatic invasion showed more significant risk of metastases to intrathoracic lymph nodes than those with other cell types or were negative for lymphatic invasion.

Univariable and multivariable analyses showed that adenocarcinoma and lymphatic invasion were predictors of intrathoracic lymph node metastases, as shown in Tables 4 and 5 .

\section{Postoperative complications}

Of the 197 patients, a lobectomy was performed in 188 cases (95.4\%) and a bilobectomy was performed in nine cases (4.6\%). Eight patients received an RLL and RML lobectomy and one case required an RUL and RML lobectomy.

Three patients $(1.5 \%)$ died after surgery. These patients developed respiratory failure, hospital-acquired pneumonia, septicemia, and multiple organ failure. They had chronic obstructive pulmonary disease, hypertension, and diabetes mellitus.

Postoperative complications included air leakage in 19 cases $(9.7 \%)$ (two cases needed a second operation to repair lung parenchyma), respiratory failure in three cases (1.5\%) (all cases had their endotracheal tube removed within one week after surgery), chylothorax in two cases (1.0\%) (one of which needed rethoracotomy for a mass ligation of the thoracic duct), hemothorax in two cases (1.0\%) (one case had bleeding from an intercostal artery and another case had bleeding from a raw surface after trying to dissect the tumor from the parietal pleura; both cases required reoperation to stop the bleeding), and atelectasis in three cases (1.5\%) (caused by secretion obstruction and treated with a bronchoscopy with suction). The summary of postoperative complications and lengths of hospital stays are shown in Table 6.

Table 4 Univariable logistic regression analysis of factors that influence positive malignant cells in intrathoracic lymph nodes

\begin{tabular}{llll}
\hline Factors & Odds ratio & $\mathbf{9 5 \%} \mathbf{C l}$ & $\mathbf{P}$ value \\
\hline Size & 1.0 & $0.9-\mathrm{I} . \mathrm{I}$ & $0.85 \mathrm{I}$ \\
Adenocarcinoma* & 4.3 & $1.2-5.0$ & 0.022 \\
Lymphatic invasion** $_{\text {Severe and undifferentiated*** }}$ & 3.6 & $1.3-9.8$ & 0.013 \\
\hline
\end{tabular}

Notes: *Compared with other cell types; **compared with negative lymphatic invasion; ****compared with well and moderately differentiated.

Abbreviation: $\mathrm{Cl}$, confidence interval.
Table 5 Multivariable logistic regression analysis of factors that influence the positive malignant cells in intrathoracic lymph nodes

\begin{tabular}{llll}
\hline Factors & Odds ratio & $\mathbf{9 5 \%} \mathbf{C l}$ & $\boldsymbol{P}$ value \\
\hline Size & 1.0 & $0.9-1.2$ & $0.6 \mathrm{I} 4$ \\
Adenocarcinoma* & 4.3 & $1.1-16.3$ & 0.034 \\
Lymphatic invasion** $_{\text {Severe and undifferentiated*** }}$ & 3.2 & $1.1-9.1$ & $0.03 \mathrm{I}$ \\
\hline
\end{tabular}

Notes: *Compared with other cell types; **compared with negative lymphatic invasion; ****compared with well and moderately differentiated.

Abbreviation: $\mathrm{Cl}$, confidence interval.

\section{Distribution of nodes in each location}

The distribution of pathological nodal status according to the location of primary tumors is shown in Table 7 . The rate of lower mediastinal node metastases in patients who had tumors located in their RLL was significantly higher than that of patients who had tumors located in their RUL (odds ratio $=10.4, P$ value $=0.007$, calculated by multivariable logistic regression analysis, shown in Tables 8 and 12). The rate of lower mediastinal node metastases in patients who had a tumor located in the LLL was significantly higher than that of patients who had a tumor located in the LUL (Table 9). However, there was no statistically significant difference when calculated using multivariable logistic regression analysis, as shown in Table 12.

Table 13 shows the relationship between the location of the primary tumor and the prevalence of skip mediastinal lymph node metastases. Skip metastases was defined as metastatic foci in the mediastinal lymph node group, whereas the hilar mediastinal nodes were negative. Approximately $9.1 \%$ of patients (18 patients) in this study had skip metastases. There were eleven (10.3\%) of 107 patients with primary tumors of the upper lobe who exhibited skip metastases versus four $(8.7 \%)$ of 46 patients with primary tumors of the lower lobe (not significant, $P$ value $=0.738)$.

Table 14 shows the relationship between the primary tumor site with positive intrathoracic lymph node metastases and the level of mediastinal lymph node metastases.

Table 6 Postoperative status and complications

\begin{tabular}{ll}
\hline Postoperative status & Number of patients (\%) \\
\hline No complication & $165(83.7)$ \\
Air leak & $19(9.7)$ \\
Respiratory failure & $3(1.5)$ \\
Chylothorax & $2(1.0)$ \\
Hemothorax & $2(1.0)$ \\
Atelectasis & $3(1.5)$ \\
Death & $3(1.5)$ \\
Hospital stay, days (mean \pm SD) & $8.8 \pm 5.1$ \\
\hline
\end{tabular}


Table 7 Distribution of nodes in each location

\begin{tabular}{|c|c|c|c|c|c|}
\hline LN station & $\begin{array}{l}\text { RUL (N = 2I) } \\
\text { N (\%) }\end{array}$ & $\begin{array}{l}\text { RML }(\mathbf{N}=6) \\
\text { N (\%) }\end{array}$ & $\begin{array}{l}\text { RLL }(\mathbf{N}=13) \\
\mathbf{N}(\%)\end{array}$ & $\begin{array}{l}\text { LUL }(\mathbf{N}=2 \mathrm{I}) \\
\mathbf{N}(\%)\end{array}$ & $\begin{array}{l}\operatorname{LLL}(\mathrm{N}=4) \\
\mathrm{N}(\%)\end{array}$ \\
\hline \multicolumn{6}{|l|}{ Positive } \\
\hline $\begin{array}{l}\text { Upper mediastinal node } \\
\text { (station I-4) }\end{array}$ & $12(57.1)$ & $2(33.3)$ & $5(38.5)$ & 7 (33.3) & $2(50.0)$ \\
\hline $\begin{array}{l}\text { Lower mediastinal node } \\
\text { (station 7-9) }\end{array}$ & $2(9.52)$ & $3(50.0)$ & $9(69.2)$ & 7 (33.3) & $4(100.0)$ \\
\hline $\begin{array}{l}\text { Intrapulmonary node } \\
\text { (station 10-14) }\end{array}$ & $21(100.0)$ & $5(83.3)$ & I3 (I00.0) & $21(100.0)$ & $4(100.0)$ \\
\hline $\begin{array}{l}\text { AP window node } \\
\text { (station 5-6) }\end{array}$ & - & - & - & $12(57.1)$ & $2(50.0)$ \\
\hline
\end{tabular}

Abbreviations: RUL, right upper lobe; RML, right middle lobe; RLL, right lower lobe; LUL, left upper lobe; LLL, left lower lobe; LN, lymph node.

Sixty-eight (34.5\%) patients had pathologically proven mediastinal lymph node metastases despite being clinically negative for mediastinal lymph node metastases and 52.9\% of patients who were clinically negative for mediastinal lymph node metastases showed multiple-level mediastinal metastases. There was no statistically significant difference between the sites of primary tumors that had intra-thoracic lymph node metastases and the level of mediastinal lymph node metastases $(P$ value $=0.223$ based on a Fisher exact probability test).

\section{Discussion}

Lymph node dissection of the pulmonary hilum and mediastinum combined with a lobectomy was first introduced by Cahan ${ }^{11}$ as an alternative to the pneumonectomy, which was respected as a standard mode of surgery. Cahan first postulated that the extent of dissection should be based on the lobe where the primary tumor was located and stated that a bilobectomy should be performed for tumors of the RML or RLL. However, his proposal regarding the extent of dissection was not based on a detailed analysis of the incidence of involvement in each mediastinal location.

The dissection of a mediastinal lymph node in each station with the least possibility of metastasis increases the

Table 8 Distribution of metastatic lymph nodes compared with site of tumor between RUL and RLL

\begin{tabular}{llll}
\hline Intrathoracic LN group & $\begin{array}{l}\text { RUL } \\
\text { N (\%) }\end{array}$ & $\begin{array}{l}\text { RLL } \\
\text { N (\%) }\end{array}$ & P value \\
\hline $\begin{array}{l}\text { Upper mediastinal node } \\
\text { (station I-4) }\end{array}$ & $12(57.1)$ & $5(38.5)$ & 0.48 I \\
$\begin{array}{l}\text { Lower mediastinal node } \\
\text { (station 7-9) }\end{array}$ & $2(9.5)$ & $9(69.2)$ & 0.00 I \\
$\begin{array}{l}\text { Intrapulmonary node } \\
\text { (station 10-14) }\end{array}$ & $21(100.0)$ & $13(100.0)$ & - \\
\hline
\end{tabular}

Abbreviations: RUL, right upper lobe; RML, right middle lobe; RLL, right lower lobe. rate of morbidity and mortality, operative time, and blood loss and has the least efficacy. If the lymphatic drainage route and incidence of lymph node metastasis correlated to the anatomical location of the lobe that involved the primary tumor, the optimal extent of lymph node dissection should be based on the incidence of metastasis to each mediastinal station.

Systematic nodal dissection in lung cancer is our routine procedure despite clinical stage I non-small cell lung cancer (NSCLC) because of the relatively high false negative rate of CT scanning. ${ }^{12-14}$ We categorize the mediastinal lymph nodes according to the classification by the International Association for the Study of Lung Cancer, which has been universally accepted since its introduction (first introduced by Naruke et $\mathrm{al}^{20}$ ). There were few complications of mediastinal lymph node dissection, such as chylothorax, in this series (only 1\%) and overall complications were $16.3 \%$, mainly due to postoperative air leakage. The 30-day mortality rate was $1.3 \%$.

Our data demonstrated adenocarcinoma and intratumoral lymphatic invasions are influencing factors for the incidence and extent of metastasis of intrathoracic lymph nodes in

Table 9 Distribution of metastatic lymph nodes compared with site of tumor between LUL and LLL

\begin{tabular}{llll}
\hline Intrathoracic LN group & $\begin{array}{l}\text { LUL } \\
\text { N (\%) }\end{array}$ & $\begin{array}{l}\text { LLL } \\
\text { N (\%) }\end{array}$ & P value \\
\hline $\begin{array}{l}\text { Upper mediastinal node } \\
\text { (station 1-4) }\end{array}$ & $7(33.3)$ & $2(50.0)$ & 0.602 \\
$\begin{array}{l}\text { Lower mediastinal node } \\
\text { (station 7-9) }\end{array}$ & $7(33.3)$ & $4(100.0)$ & 0.026 \\
$\begin{array}{l}\text { Aortopulmonary window node } \\
\text { (station 5, 6) }\end{array}$ & $12(57.1)$ & $2(50.0)$ & 1.000 \\
$\begin{array}{l}\text { Intrapulmonary node } \\
\text { (station 10-14) }\end{array}$ & $21(100.0)$ & $4(100.0)$ & - \\
\hline
\end{tabular}

Abbreviations: LN, lymph node; LUL, left upper lobe; LLL, left lower lobe. 
Table I 0 Distribution of metastatic lymph nodes compared with site of tumor between RUL and RML

\begin{tabular}{llll}
\hline Intrathoracic LN group & $\begin{array}{l}\text { RUL } \\
\text { N (\%) }\end{array}$ & $\begin{array}{l}\text { RML } \\
\mathbf{N}(\%)\end{array}$ & P value \\
\hline $\begin{array}{l}\text { Upper mediastinal node } \\
\text { (station I-4) }\end{array}$ & $12(57.1)$ & $2(33.3)$ & 0.385 \\
$\begin{array}{l}\text { Lower mediastinal node } \\
\text { (station 7-9) }\end{array}$ & $2(9.5)$ & $3(50.0)$ & 0.056 \\
$\begin{array}{l}\text { Intrapulmonary node } \\
\text { (station 10-14) }\end{array}$ & $21(100.0)$ & $5(83.3)$ & 0.222 \\
\hline
\end{tabular}

Abbreviations: RUL, right upper lobe; RML, right middle lobe; LN, lymph node.

operable NSCLC patients. Those who had adenocarcinoma or intratumoral lymphatic invasion showed a significantly higher incidence of mediastinal lymph node metastases. However, the incidence of mediastinal lymph node metastases did not correlate significantly with tumor sizes, as reported in a previous study. ${ }^{15}$

The preoperative evaluation of the intrathoracic nodal status based on a CT scan remains a feature since normal sized nodes could be cancer positive upon pathological examination, as shown in Table 3. Approximately $61.7 \%$ of patients were preoperatively understaged based on the CT scan. At our institution, 69 (35\%) of 197 patients preoperatively diagnosed with no mediastinal lymph node metastasis by CT scan were revealed to be N1-2 upon pathological examination after surgery. Preoperative evaluation of nodal status by CT scan is thus not enough to decide the appropriateness of limited resection for NSCLC. ${ }^{16,17}$ Although positron emission tomography with a CT scan has been used worldwide in recent years, it remains unavailable in many countries, including Thailand.

Our data shows that more than half $(52.9 \%)$ of clinical node negative patients showed multiple-level mediastinal metastases. The results of this study are similar to those of Keller and associates (Eastern Cooperative Oncology Group), ${ }^{18}$ who reported that complete mediastinal lymph

Table I I Distribution of metastatic lymph nodes compared with site of tumor between RLL and RML

\begin{tabular}{llll}
\hline Intrathoracic LN group & $\begin{array}{l}\text { RLL } \\
\text { N (\%) }\end{array}$ & $\begin{array}{l}\text { RML } \\
\text { N (\%) }\end{array}$ & P value \\
\hline $\begin{array}{l}\text { Upper mediastinal node } \\
\text { (station 1-4) }\end{array}$ & $5(38.5)$ & $4(66.7)$ & 1.000 \\
$\begin{array}{l}\text { Lower mediastinal node } \\
\text { (station 7-9) }\end{array}$ & $9(69.2)$ & $3(50.0)$ & 0.617 \\
$\begin{array}{l}\text { Intrapulmonary node } \\
\text { (station 10-14) }\end{array}$ & $13(100.0)$ & $5(83.3)$ & 0.316 \\
\hline
\end{tabular}

Abbreviations: LN, lymph node; RML, right middle lobe; RLL, right lower lobe.
Table 12 Multivariable logistic regression analysis of intrathoracic lymph node metastases compared among upper, lower, and middle lobes (confounders include size of tumor, histology type, cell differentiated, and lymphatic invasion)

\begin{tabular}{|c|c|c|c|}
\hline Intrathoracic lymph nodes & Odds ratio & $95 \% \mathrm{Cl}$ & $P$ value \\
\hline \multicolumn{4}{|l|}{ RLL vs RUL } \\
\hline $\begin{array}{l}\text { Upper mediastinal node } \\
\text { (station 1-4) }\end{array}$ & 0.7 & $0.2-2.4$ & 0.543 \\
\hline $\begin{array}{l}\text { Lower mediastinal node } \\
\text { (station 7-9) }\end{array}$ & 10.4 & $1.9-58.0$ & 0.007 \\
\hline $\begin{array}{l}\text { Intrapulmonary node } \\
\text { (station 10-14) }\end{array}$ & 1.2 & $0.4-3.6$ & 0.687 \\
\hline \multicolumn{4}{|l|}{ RLL vs RML } \\
\hline $\begin{array}{l}\text { Upper mediastinal node } \\
\text { (station I-4) }\end{array}$ & 3.0 & $0.4-23.7$ & 0.301 \\
\hline $\begin{array}{l}\text { Lower mediastinal node } \\
\text { (station 7-9) }\end{array}$ & 1.8 & $0.3-1.5$ & 0.515 \\
\hline $\begin{array}{l}\text { Intrapulmonary node } \\
\text { (station } 10-14 \text { ) }\end{array}$ & 2.6 & $0.5-15.1$ & 0.284 \\
\hline \multicolumn{4}{|l|}{ RUL vs RML } \\
\hline $\begin{array}{l}\text { Upper mediastinal node } \\
\text { (station 1-4) }\end{array}$ & 0.6 & $0.1-3.1$ & 0.550 \\
\hline $\begin{array}{l}\text { Lower mediastinal node } \\
\text { (station 7-9) }\end{array}$ & 6.4 & $0.9-44.5$ & $0.06 \mathrm{I}$ \\
\hline $\begin{array}{l}\text { Intrapulmonary node } \\
\text { (station 10-14) }\end{array}$ & 0.7 & $0.2-3.0$ & 0.642 \\
\hline \multicolumn{4}{|l|}{ LLL vs LUL } \\
\hline $\begin{array}{l}\text { Upper mediastinal node } \\
\text { (station } 1-4 \text { ) }\end{array}$ & 0.7 & $0.1-4.4$ & 0.748 \\
\hline $\begin{array}{l}\text { Lower mediastinal node } \\
\text { (station 7-9) }\end{array}$ & 1.6 & $0.4-7.0$ & 0.534 \\
\hline $\begin{array}{l}\text { Aortopulmonary window node } \\
(\text { station } 5,6)\end{array}$ & 0.4 & $0.1-2.3$ & 0.312 \\
\hline
\end{tabular}

Abbreviations: $\mathrm{Cl}$, confidence interval; $\mathrm{RUL}$, right upper lobe; $\mathrm{RML}$, right middle lobe; RLL, right lower lobe; LUL, left upper lobe; LLL, left lower lobe.

node dissection had identified significantly more levels of mediastinal involvement, but in patients with small sized NSCLC.

Okada et $\mathrm{al}^{19}$ and Naruke et $\mathrm{al}^{20}$ show that tumors in the RUL developed extensive multiple-level mediastinal involvement within the upper, middle, and lower mediastinal lymph nodes, whereas tumors originating in the LUL

Table I 3 Location of primary tumor and skip nodal metastases

\begin{tabular}{lll}
\hline $\begin{array}{l}\text { Primary } \\
\text { tumor site }\end{array}$ & $\begin{array}{l}\text { No skip metastases } \\
\text { N (\%) }\end{array}$ & $\begin{array}{l}\text { Skip metastases } \\
\text { N (\%) }\end{array}$ \\
\hline RUL $(n=63)$ & $58(92.1)$ & $5(7.9)$ \\
RML $(n=18)$ & $15(83.3)$ & $3(16.7)$ \\
RLL $(n=30)$ & $26(86.7)$ & $4(13.3)$ \\
LUL $(n=55)$ & $49(89.1)$ & $6(10.9)$ \\
LLL $(n=16)$ & $16(100.0)$ & $0(0.0)$ \\
\hline
\end{tabular}

Note: Skip metastases were defined as metastatic foci in the mediastinal lymph node (N2) group without metastasis to the hilar mediastinal node.

Abbreviations: RUL, right upper lobe; RML, right middle lobe; RLL, right lower lobe; LUL, left upper lobe; LLL, left lower lobe. 
Table I4 Location of primary tumor and multi-level mediastinal lymph node metastases

\begin{tabular}{lll}
\hline $\begin{array}{l}\text { Primary tumor site } \\
\text { with intrathoracic } \\
\text { LN metastases }\end{array}$ & $\begin{array}{l}\text { Single level } \\
\text { mediastinal LN } \\
\text { metastases } \\
\mathbf{N}(\%)\end{array}$ & $\begin{array}{l}\text { Multi-level } \\
\text { mediastinal LN } \\
\text { metastases } \\
\mathbf{N}(\%)\end{array}$ \\
\hline RUL $(n=2 I)$ & $13(61.9)$ & $8(38.1)$ \\
RML $(n=6)$ & $4(66.8)$ & $2(33.2)$ \\
RLL $(n=13)$ & $5(38.5)$ & $8(61.5)$ \\
LUL $(n=21)$ & $9(42.9)$ & $12(57.1)$ \\
LLL $(n=4)$ & $0(0.0)$ & $4(100.0)$ \\
RML and RLL $(n=3)$ & $1(33.3)$ & $2(66.7)$ \\
Total $(n=68)$ & $32(47.1)$ & $36(52.9)$ \\
\hline
\end{tabular}

Notes: Single level refers to either intrapulmonary lymph node $(\mathrm{NI})$ group or mediastinal lymph node (N2) group mediastinal LN metastases; Multi-level refers to both $\mathrm{NI}$ group and $\mathrm{N} 2$ group mediastinal LN metastases. ( $P$ value $=0.223$ by Fisher exact probability test).

Abbreviation: LN, lymph node.

metastasized within the upper, lower, and aortopulmonary window mediastinal lymph nodes. These results complement our findings. Only tumors located in the RUL have more risk for metastases to the upper mediastinal lymph nodes than those in the RLL. However, tumors from other sites have no statistically significant difference in the level of mediastinal lymph node metastases. Therefore, the pattern of mediastinal lymph node metastasis is not compatible with the primary site of the tumor. However, $40 \%$ of lower lobe (RLL and LLL) with mediastinal lymph node metastases had nodal metastasis to the upper mediastinal lymph node and $20 \%$ of upper lobe (RUL and LUL) with mediastinal lymph node metastases had nodal metastasis to the lower mediastinal lymph node. This incidence was lower than that in previous reports. ${ }^{15,21}$ In the aortopulmonary window node, the LUL lesion tends to metastasize more than in the LLL lesion, but this finding is not statistically significant.

Takizawa et $\mathrm{al}^{22}$ and Oda et $\mathrm{al}^{15}$ show that the location of the primary tumor corresponds to the mediastinal area where lymph nodes are likely to be diseased and that the frequency of nodal metastasis of a single level is high. This was also seen in our series, as shown in Tables 13 and 14. There are $9.6 \%$ more cases of skip metastasis than were found in a previous study. ${ }^{23}$

\section{Conclusion}

There is no definite way to identify lymphatic spreading. It seems that upper lobe lesions not only metastasize to an upper mediastinal node level, but also metastasize to a lower mediastinal node level. On the contrary, lower lobe lesions not only metastasize to a lower mediastinal node level, but also involve the upper mediastinal node level. Tumor location alone is no longer a predictive factor for the pattern of nodal involvement; therefore, systematic lymph node dissection remains the only way for us to determine lymph node status. However, further studies are required for evaluation and conclusions regarding this view.

\section{Disclosure}

The authors report no conflicts of interest in this work.

\section{References}

1. T Khuhaprema PS, Attasara P, Sriplung H, Wiangnon S, Sumitsawan Y, editors. Cancer in Thailand. Bangkok: Ministry of Public Health; 2010; 2001-2003.

2. Su X, Wang X, Long H, et al. Mediastinal lymph node dissection affects survival in patients with stage I non-small cell lung cancer. Thorac Cardiovasc Surg. 2008;56(4):226-230.

3. Wu N, Lv C, Yan S, et al. Systemic mediastinal lymph node dissection of right lung cancer: surgical quality control and analysis of mediastinal lymph node metastatic patterns. Interact Cardiovasc Thorac Surg. 2008; 7(2):240-243.

4. Bolukbas S, Eberlein MH, Schirren J. Role of mediastinal lymph node dissection in non-small cell lung cancer. Front Radiat Ther Oncol. 2010; 42:78-86.

5. Watanabe S, Asamura H. Lymph node dissection for lung cancer: significance, strategy, and technique. J Thorac Oncol. 2009; 4(5):652-657.

6. Wu N, Yan S, Lv C, et al. Comparison of systematic mediastinal lymph node dissection versus systematic sampling for lung cancer staging and completeness of surgery. J Surg Res. 2011;171(2): e169-e173.

7. Iwasaki A, Hamatake D, Hamanaka W, et al. Is systemic node dissection for accuracy staging in clinical stage I non-small cell lung cancer worthwhile in the elderly? Thorac Cardiovasc Surg. 2008; 56(1):37-41.

8. Ishiguro F, Matsuo K, Fukui T, Mori S, Hatooka S, Mitsudomi T. Effect of selective lymph node dissection based on patterns of lobespecific lymph node metastases on patient outcome in patients with resectable non-small cell lung cancer: a large-scale retrospective cohort study applying a propensity score. J Thorac Cardiovasc Surg. 2010; 139(4):1001-1006.

9. Hughes MJ, Chowdhry MF, Woolley SM, Walker WS. In patients undergoing lung resection for non-small cell lung cancer, is lymph node dissection or sampling superior? Interact Cardiovasc Thorac Surg. 2011; 13(3):311-315.

10. Goldstraw P, editor. Staging Manual in Thoracic Oncology. Denver, CO, USA: John Wiley and Sons Ltd; 2009.

11. Cahan WG. Radical lobectomy. J Thorac Cardiovasc Surg. 1960; 39:555-572.

12. Watanabe Y, Shimizu J, Oda M, et al. Aggressive surgical intervention in N2 non-small cell cancer of the lung. Ann Thorac Surg. 1991; 51(2):253-261.

13. Lee KS, Jeong YJ, Han J, Kim BT, Kim H, Kwon OJ. T1 non-small cell lung cancer: imaging and histopathologic findings and their prognostic implications. Radiographics. 2004;24(6):1617-1636.

14. Watanabe S OM, Go T, Tsunezuka Y. Should mediastinal nodal dissection be routinely undertaken in patients with peripheral small-sized ( $2 \mathrm{~cm}$ or less ) lung cancer? Retrospective analysis of 225 patients. Eur $J$ Cardiothorac Surg. 2001;20:1007-1011.

15. Oda M, Watanabe Y, Shimizu J, et al. Extent of mediastinal node metastasis in clinical stage I non-small-cell lung cancer: the role of systematic nodal dissection. Lung Cancer. 1998;22(1): $23-30$. 
16. Izbicki JR, Thetter O, Karg O, et al. Accuracy of computed tomographic scan and surgical assessment for staging of bronchial carcinoma. A prospective study. J Thorac Cardiovasc Surg. 1992; 104(2):413-420.

17. Suzuki K, Nagai K, Yoshida J, Nishimura M, Nishiwaki Y. Predictors of lymph node and intrapulmonary metastasis in clinical stage IA nonsmall cell lung carcinoma. Ann Thorac Surg. 2001;72(2):352-356.

18. Keller SM, Adak S, Wagner H, Johnson DH. Mediastinal lymph node dissection improves survival in patients with stages II and IIIa non-small cell lung cancer. Eastern Cooperative Oncology Group. Ann Thorac Surg. 2000;70(2):358-365; discussion 365-356.

19. Okada M, Tsubota N, Yoshimura M, Miyamoto Y. Proposal for reasonable mediastinal lymphadenectomy in bronchogenic carcinomas: role of subcarinal nodes in selective dissection. J Thorac Cardiovasc Surg. 1998;116(6):949-953.
20. Naruke T, Tsuchiya R, Kondo H, Nakayama H, Asamura H. Lymph node sampling in lung cancer: how should it be done? Eur J Cardiothorac Surg. 1999;16 Suppl 1:S17-S24.

21. Watanabe Y, Shimizu J, Tsubota M, Iwa T. Mediastinal spread of metastatic lymph nodes in bronchogenic carcinoma. Mediastinal nodal metastases in lung cancer. Chest. 1990;97(5):1059-1065.

22. Takizawa T, Terashima M, Koike T, Akamatsu H, Kurita Y, Yokoyama A. Mediastinal lymph node metastasis in patients with clinical stage I peripheral non-small-cell lung cancer. J Thorac Cardiovasc Surg. 1997; 113(2):248-252.

23. Kotoulas CS, Foroulis CN, Kostikas K, et al. Involvement of lymphatic metastatic spread in non-small cell lung cancer accordingly to the primary cancer location. Lung Cancer. 2004;44(2):183-191.
Cancer Management and Research

\section{Publish your work in this journal}

Cancer Management and Research is an international, peer-reviewed open access journal focusing on cancer research and the optimal use of preventative and integrated treatment interventions to achieve improved outcomes, enhanced survival and quality of life for the cancer patient. The journal welcomes original research, clinical \& epidemiological studies, reviews \& evaluations, guidelines, expert opinion \& commentary, case reports \& extended reports. The manuscript management system is completely online and includes a very quick and fair peerreview system, which is all easy to use. Visit http://www.dovepress.com/ testimonials.php to read real quotes from published authors.

Submit your manuscript here: http://www.dovepress.com/cancer-management-and-research-journal 